ANL-6934

ANL-6934

Argonne Jational Laboratoru

INTERBUILDING FUEL TRANSFER COFFIN

FOR THE EBR-II REACTOR

by

G. J. Bernstein, A. A. Chilenskas,

and R. F. Malecha 


\section{DISCLAIMER}

This report was prepared as an account of work sponsored by an agency of the United States Government. Neither the United States Government nor any agency Thereof, nor any of their employees, makes any warranty, express or implied, or assumes any legal liability or responsibility for the accuracy, completeness, or usefulness of any information, apparatus, product, or process disclosed, or represents that its use would not infringe privately owned rights. Reference herein to any specific commercial product, process, or service by trade name, trademark, manufacturer, or otherwise does not necessarily constitute or imply its endorsement, recommendation, or favoring by the United States Government or any agency thereof. The views and opinions of authors expressed herein do not necessarily state or reflect those of the United States Government or any agency thereof. 


\section{DISCLAIMER}

Portions of this document may be illegible in electronic image products. Images are produced from the best available original document. 


\section{LEGAL NOTICE}

This report was prepared as an account of Government sponsored work. Neither the United States, nor the Commission, nui any pereon arting on behalf of the Commission:

A. Makes any warranty or representation, expressed or implied, with respect w the accuracy, completeness, or usefulness of the information contained in this report, or that the use of any information, apparatus, method, or process disclosed in this report may not infringe privately owned rights; or

B. Assumes any liabilities with respect to the use of, or for damages resulting from the use of any information, apparatus, method, or process disclosed in this report.

As used in the above, "person acting on behalf of the Commission" includes any employee or contractor of the Commission, or employee of such contractor, to the extent that such employee or contractor of the Commission, or employee of such contractor prepares, disseminates, or provides access to, any information pursuant to his employment or contract with the Commission, or his employment with such contractor.

Printed in USA. Price $\$ 2.00$. Available from the Clearinghouse for Federal Scientific and Technical Information, National Bureau of Standards,

U. S. Department of Commerce, Springfield, Virginia 
ANL-6934

Reactór Technology

(TID-4500, 37th Ed.)

AEC Research and

Development Report

ARGONNE NATIONAL LABORATORY

9700. South Cass Avenue

Argonne, Illinois 60440

\section{INTERBUILDING FUEL TRANSFER COFFIN \\ FOR THE EBR-II REACTOR}

by

G. J. Bernstein, A. A. Chilenskas, and R. F. Malecha

Chemical Engineering Division

September 1964

Operated by The University of Chicago under

Contract W-31-109-eng-38

with the

U. S. Atomic Energy Commission 
TABLE OF CONTENTS

$\underline{\text { Page }}$

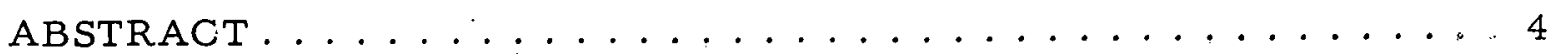

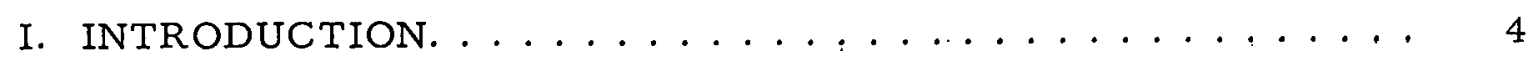

II. DESCRIPTION OF THE INTERBUILDING FUEL TRANSFER

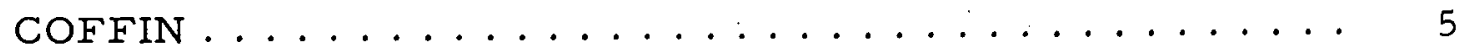

III. OPERATION OF THE INTERBUILDING FUEL TRANSFER

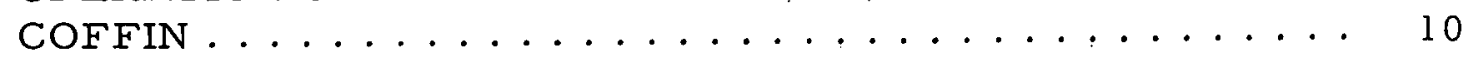

IV. HEAT EXCHANGER AND INSERT TUBES. . . . . . . . . 14

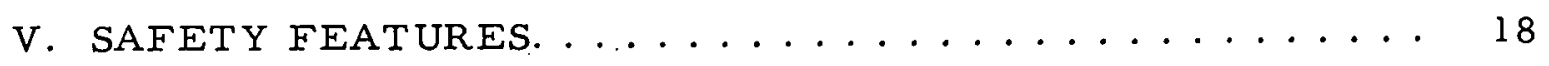

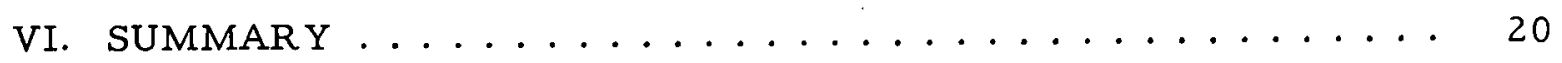

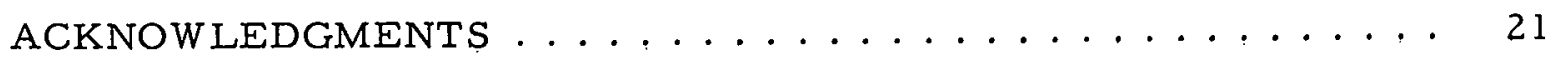

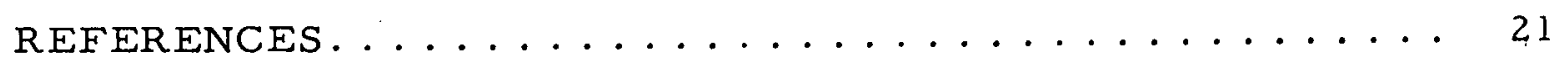




\section{LIST OF FIGURES}

No.

Title

Page

1. Fuel Transfer Coffin, Front View ............... 6

2. Fuel Transfer Coffin, Internal Construction .......... 6

3. Fuel Transfer Coffin; Gas Circulation System. . . . . . . . 7

4. EBR-II Fuel Subassembly ................... 8

5. Reactor Passageway and Movement of the Interbuilding Fuel Transfer Coffin between the Reactor and Fuel Cycle Facility. .

6. Heat Removal Performance Tests on Interbuilding Fuel

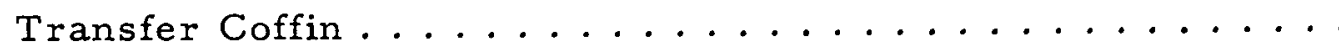

7. Temperature Rise in Fuel Subassembly without Forced Cooling.

TABLE

No. Title Pago

I. Temperature Rise in Fuel Subassembly within the Fuel Transfer Coffin, Following Loss of Coolant........... 


\title{
INTERBUILDING FUEL TRANSFER COFFIN FOR THE EBR-II REACTOR
}

\author{
by \\ G. J. Bernstein, A. A. Chilenskas, \\ and.R. F. Malecha
}

\begin{abstract}
A 20-ton, portable, lead-shielded coffin has been built to transfer spent fuel subassemblies from the EBR-II Reactor to the adjoining Fuel Cycle Facility for processing. Fission-product heat of about $1 \mathrm{~kW}$ is removed by a circulating gas stream which is driven by an attached batterypowered blower. An internal heat exchanger transfers the heat from the coolant gas to the lead shielding.
\end{abstract}

Provision is made for removing a coating of sodium from the fuel subassembly while it is within the coffin.

The principal design features and operations are described.

\section{INTRODUCTION}

The Experimental Breeder Reactor-II (EBR-II) operates on a closed fuel cycle. Spent fuel is recycled through a Fuel Cycle Facility where it is decontaminated and refabricated for return to the reactor. $(1,2)$ Under normal operating conditions, a fuel subassembly is removed from the reactor core after 2 a/o burnup in 135 days. It is cooled for 15 days in the reactor sodium pool and then transferred to the Fuel Cycle Facility. Normal processing rate requires one such subassembly transfer in both directions every second day.

A subassembly. ready for transfer is removed from the reactor pool through a top loading port by means of a fuel unloading machine. This machine is then driven to a pit where it discharges the subassembly into the fuel transfer coffin. The coffin carries the subassembly to the Fuel Cycle Facility where it is removed for processing. A refabricated subassembly is returned to the reactor by reversing the sequence. 
The fuel transfer coffin must fulfill the following requirements:

1. Precise alignment with the fuel unloading machine to permit transfer of subassemblies.

2. Adequate shielding for the highly radioactive fuel.

3. Leak tightness to maintain an inert internal atmosphere and to prevent escape of radioactive gases which might be released through damaged fuel cladding.

4. Provision for removing fission-product heat generated within the fuel.

5. Integral power supply for the cooling system, since.it must pass through an equipment lock.

6. Provision for removing the coating of sodium that remains on the subassembly surface when it is removed from the reactor.

7. Suitability for handling a variety of subas semblies.

In addition, severe restrictions on overall dimensions were imposed by a requirement that the coffin had to fit the available head room and openings of the Reactor Building equipment lock.

The design that was adopted and built consists of a steel coffin containing an internal tube surrounded by lead shielding. The subassembly is held within an insert tube which fits the center tube of the coffin. Fission heat is removed by a gas stream which flows through the subassembly and then through a heat exchanger which surrounds the center tube. The coolant gas is circulated by a positive-displacement blower driven by a batterypowered motor:

\section{DESCRIPTION OF THE INTERBUILDING FUEL TRANSFER COFFIN}

The general features as well as the function of the operating components of the coffin are shown in Figures.1, 2, and. 3 .

The main body of the coffin is a steel cylinder about $10 \mathrm{ft}$ high and 32 in. in diameter. All interior components, the external piping and valves, and the top plate are made of stainless steel. The external shell is made of mild steel.

A subassembly.is carried within a center tube surrounded by lead shielding. The lead is $13 \mathrm{in.} \mathrm{thick} \mathrm{at} \mathrm{the} \mathrm{sides} \mathrm{above} \mathrm{the} \mathrm{support} \mathrm{ring}$. Below the ring, the shielding thickness is gradually reduced to 7 in. because of the lower radiation associated with the bottom section of a fuel 
subassembly. The radiation level at the surface of the coffin will be less than $1 \mathrm{mR} / \mathrm{hr}$. The total weight of the coffin and attached equipment is about 19 tons, although the nominal designation " 20 tons" is used.

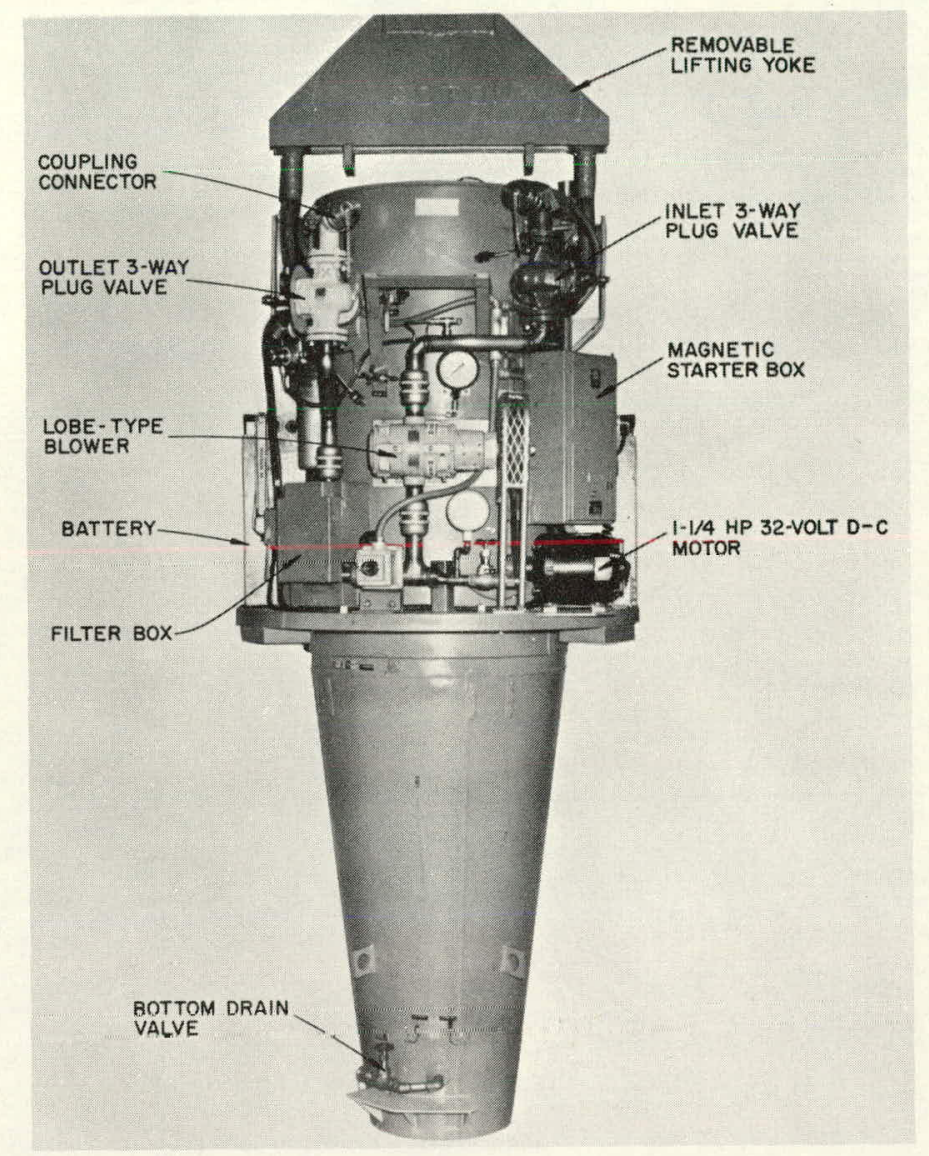

Figure 1

FUEL TRANSFER COFFIN, FRONT VIEW

$108-7159$

Figure 2

FUEL TRANSFER COFFIN, INTERNAL CONSTRUCTION

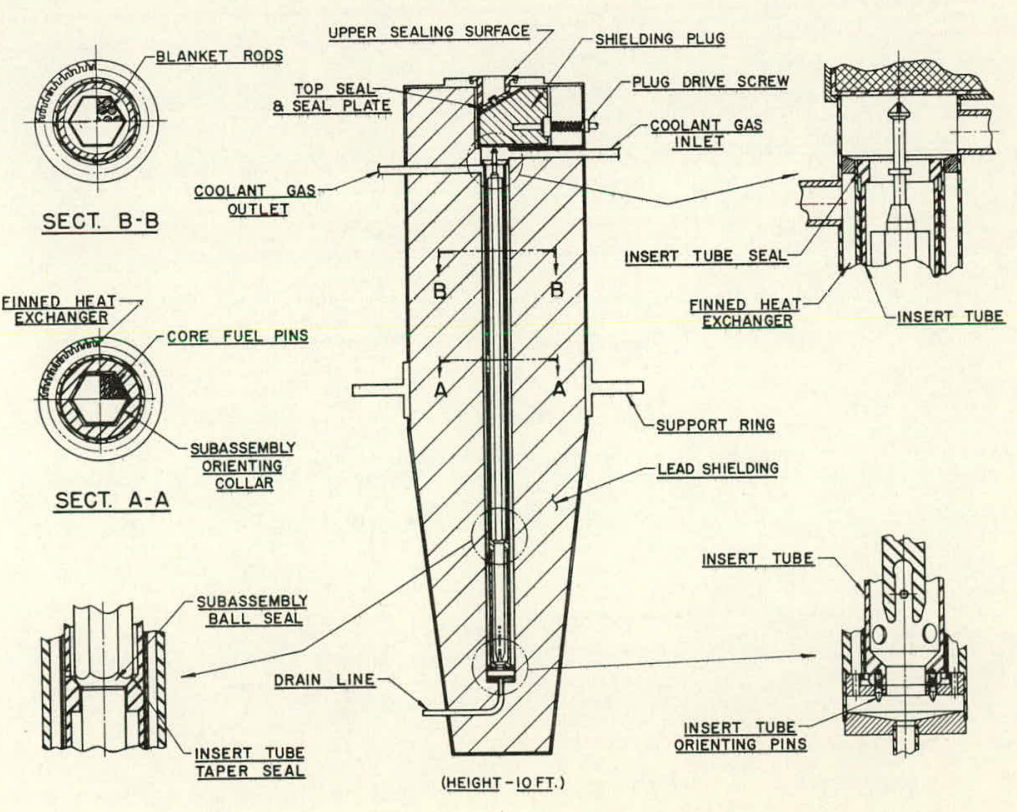


Figure 3

FUEL TRANSFER COFFIN,

GAS CIRCULATION SYSTEM

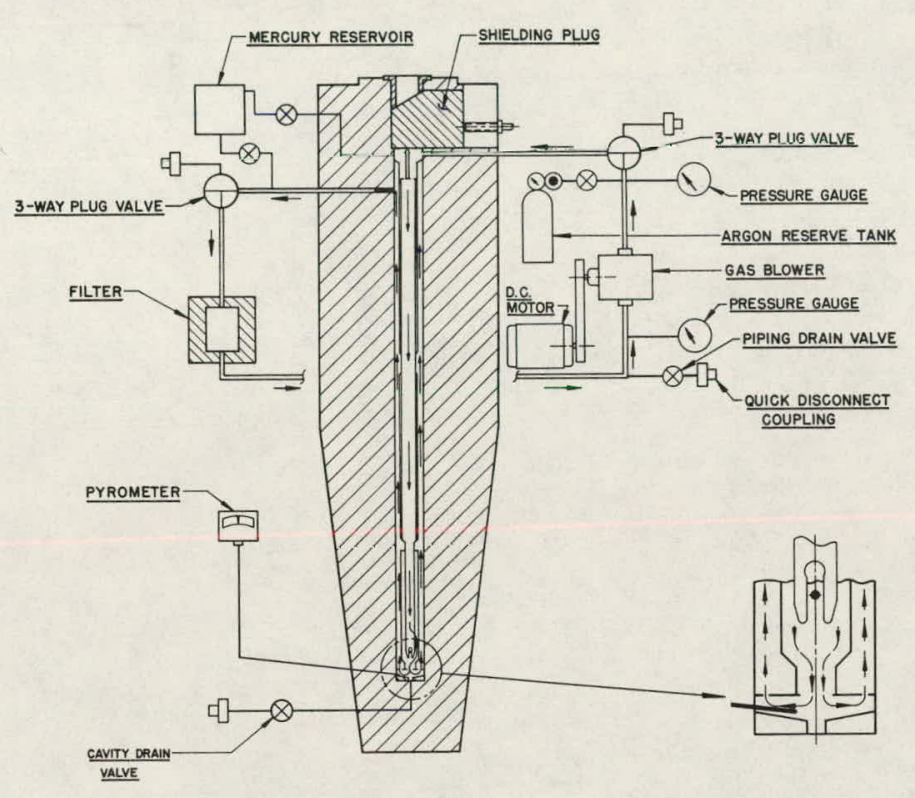

A removable insert tube which fits within the fixed center tube provides support for the subassembly and establishes a gas seal to direct coolant flow through the interior of the subassembly. Three different insert tubes are provided to accommodate the several types of subassemblies that must be transported in the coffin.

Figure 4 shows an EBR-II fuel subassembly and the details of the fuel section. The fuel section is the source of most of the fission-product heat that must be removed while the subassembly is in the coffin. The total self-heating of a fuel subassembly containing $6070 \mathrm{~g}$ of fuel that has undergone $2 \mathrm{a} / \mathrm{o}$ burnup in 135 days and has had 15 days cooling is about $1.2 \mathrm{~kW}$, if all the beta and gamma energies are absorbed. Part of the gamma energy is not absorbed in the fuel; about $1 \mathrm{~kW}$ will appear in the subassembly, and the rest will appear directly in the coffin shielding lead.

The heat developed in the fuel is removed by transfer to the lead shielding. An annular heat exchanger surrounds the fixed center tube and is bonded to the shielding lead. An external blower system circulates the coffin atmosphere down through the subassembly, and up through the heat exchanger.

The coolant gas is driven by a rotary, lobe-type, positivedisplacement blower (M. D. Blowers, Inc., Model SP-51-3202.5). This blower employs a lubricated graphite face seal. Under the conditions of operation of the coffin (maximum pressure less than 1 psig), the seal has 
tested leak-tight and the atmosphere in the coffin is oil-free. The difficulty often encountered with graphite seals operating in dry atmospheres seems to be overcome in this system as a result of the alternate use of air and dry argon as the coolant atmosphere. (This application is described in Section III.)

\section{Figure 4}

EBR-II FUEL SUBASSEMBLY

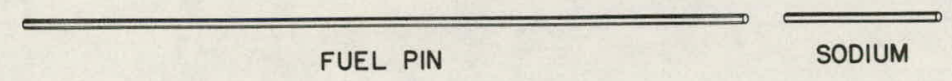

FUEL PIN

SODIUM

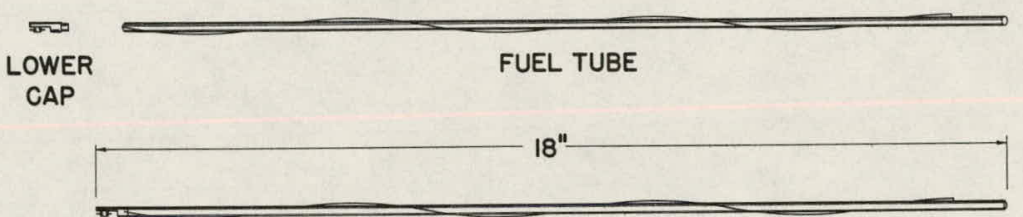

FUEL ELEMENT

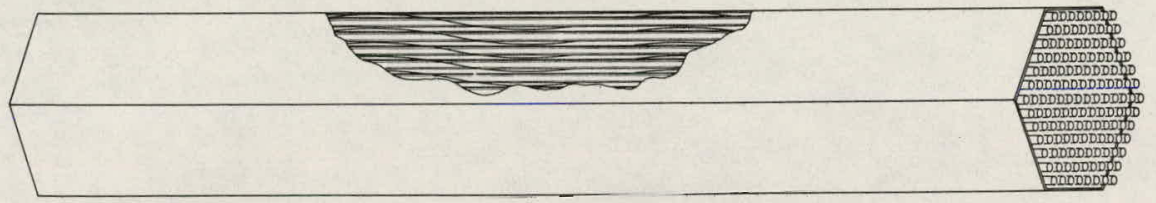

FUEL SECTION

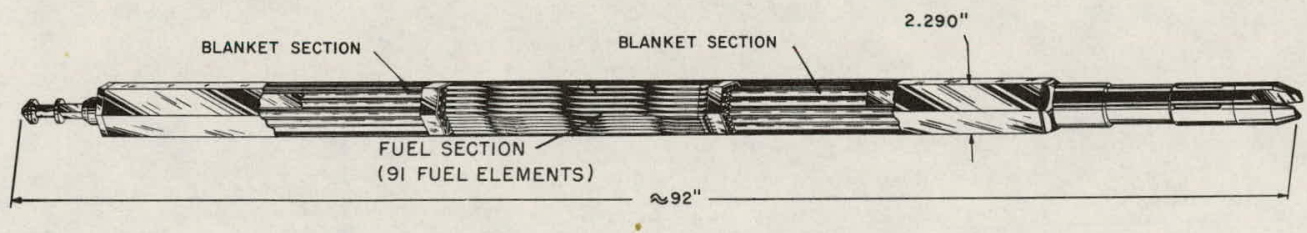

$108-2428$

The blower is driven by a General Electric $32-\mathrm{V}$ dc motor, Model $5 B C 74 A B 2050$, rated at $1-1 / 4 \mathrm{hp}$ and $3450 \mathrm{rpm}$. The blower is belt-driven with a speed reduction of $3: 1$. The use of a relatively high-speed motor was dictated by the limited space available for a motor of the required horsepower.

Power for the motor is provided by a battery consisting of 25 Exide, type E-3, nickel-iron alkaline cells. The battery has a rated voltage of $30 \mathrm{~V}$ and a rated capacity of $300 \mathrm{Amp}-\mathrm{hr}$ at a 50-Amp discharge rate. Average current consumption by the motor under operating conditions is less than $40 \mathrm{Amp}$. Tests of the blower system show a fully charged battery can drive the blower at approximately $1450 \mathrm{rpm}$ for about $4 \mathrm{hr}$. The speed then falls gradually to about $1100 \mathrm{rpm}$ after a total of $8 \mathrm{hr}$. These blower speeds are equivalent to about 32 and $22 \mathrm{cfm}$ of gas, respectively. The lower rate, $22 \mathrm{cfm}$, is adequate for heat-removal purposes. A normal transfer of a subassembly will require less than $4 \mathrm{hr}$. 
An auxiliary power system is available in the form of a Lincoln Electric Co. lead-acid battery charger which has been converted into a dc generator. The generator is driven by a $440-\mathrm{V}$ ac motor which is connected to the building's emergency power system. This generator can be used as an alternate to the battery if the coffin must operate for an extended period of time.

The battery is recharged by an Exide Model VMG-18-288, 440-V, three-phase, 60-cycle charger. The charger is equipped with a temperaturevoltage relay (TVR) which automatically terminates the charging cycle after the cells are fully charged. The charging rate varies from about 65 to 45 Amp, depending upon the state of charge in the cells.

The gas circulation loop also includes a filter for removing any particulate material such as sodium oxide which may enter the gas stream. The filter is a Cuno Model MG-1Ll and has an efficiency of $99 \%$ for 5 -micron particles at a $30-\mathrm{cfm}$ flow rate. The filter is surrounded by 2 in. of lead shielding to reduce radiation from accumulated sodium oxide. Provision exists in the gas piping for washing accumulated oxide from the filter.

As shown in Figures 1 and 2, the gas circulation loop includes two, three-way plug valves, one in the outlet line from the coffin interior (valve "X"), and the other in the inlet line (valve "Y"). These valves are Rockwell-Nordstrom No. 5713-MA-4 flanged, type 316 stainless steel, 1-1/2-in. valves with Stellite-faced plugs. The valves were modified by enlarging the port openings in the plug and body to eliminate the shut-off position when the plug is rotated from one port position to another. This construction prevents damage that might result to the blower if a valve is closed while the blower is running.

The two valves direct the flow of coolant gas through the coffin from an external circulation system during loading and unloading operations in the reactor building. A gas clean-up and circulation system in the reactor building operates in conjunction with the fuel unloading machine. When the fuel transfer coffin is coupled to the fuel unloading machine, flexible lines from the gas clean-up system are connected to valves $X$ and $Y$. Proper rotation of the valves permits the external system to purge the coffin and cool the subassembly within it. Each cooling system may operate independently, or both may operate. in parallel, as required.

External connections to valves $\mathrm{X}$ and $\mathrm{Y}$ are made through quickdisconnect couplings* attached to the valves. Each coupling half is equipped with an internal shut-off valve to reduce the amount of gas that may leak when connections are disengaged.

*Manufactured by Snap-Tite, Inc., Union City, Pennsylvania. 
The entry port of the coffin interior is located on top and is closed by a sliding plug, as shown in Figure 3 . The plug is contained within a housing and is driven by a screw which passes through a rotary seal in the housing cover plate. Limit switches indicate the position of the sliding plug. They also operate-interlock circuits on the fuel-unloading machine to permit a subassembly transfer to be initiated only when the plug is in the open position. The screw is driven by a gear motor to permit remote operation of the plug.

The port is sealed by an O-ring located on a plate which is carried by the sliding plug. The plate can pivot slightly on the plug to permit accurate alignment with the sloping underside of the top seal. The upper surface of the top seal provides the sealing surface that mates with the O-ring seal on the bottom of the fuel unloading machine when the two machines are joined.

Additional equipment items in the gas circulation system include gauges to measure inlet and outlet pressures on the rotary blower. The normal pressure drop through the system when the coffin contains a core subassembly is about 1 psi at $30 \mathrm{cfm}$. The normal maximum pressure. in the coolant system is less than 1 psi above atmospheric pressure. A small. argon supply tank is provided and can be used to increase the internal pressure. This need may arise if the pressure in the coffin is unusually low when the coffin circulation system is disengaged from the fuel unloading machine system. Undcr unusual circuristances it may also be desirable to operate the coolant system at slightly higher overall pressure to increase the heat-removal capability.

An emergency coolant tank will be located near the top of the coffin on the bracket shown between valves $X$ and $Y$. This tank will be filled with mercury which can be used to flood the coffin as an emergency coolant should the gas circulation system fail while the coffin contains a subassembly.

There are two, 3/4-in. drain valves on the coffin which are equipped with "Snap-Tite" couplings. The bottom drain valve removes water that remains in the coffin following the sodium cleanup operation (which is described in Section III). The upper drain valve is in the external gas-circulation system and removes solutions added to wash particulate sodium oxide from the filter.

\section{OPERATION OF THE INTERBUILDING FUEL TRANSFER COFFIN}

A brief description of the fuel transfer operation will identify the functions of the components of the fuel transfer coffin. The principal steps in this operation are shown in Figure 5. 
Figure 5
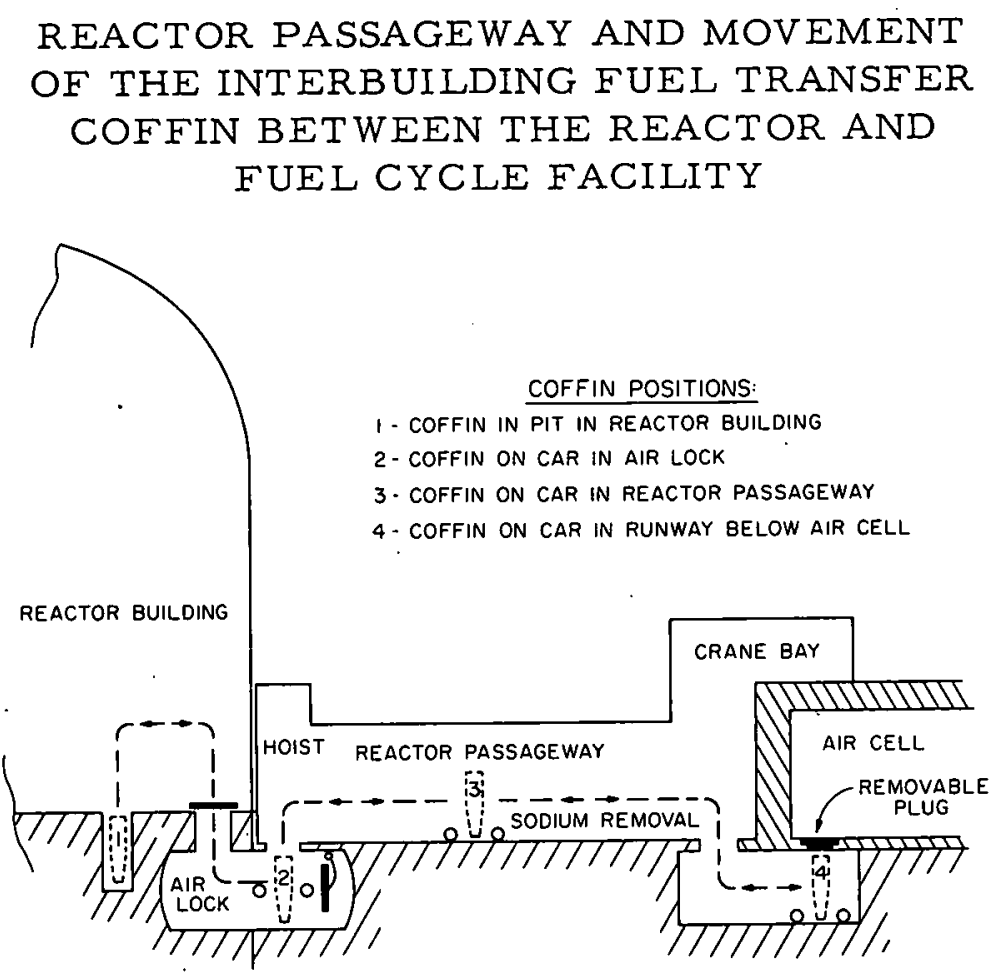

After being removed from the reactor, a spent fuel subassembly is allowed to cool for 15 days in the sodium pool of the reactor tank. The fuel unloading machine, which travels on precision rails, is moved into position above the reactor tank loading port. The fuel unloading machine is sealed to the flange above the port by means of a spring-loaded O-ring on the bottom of the machine. The space between the bottom port of the fuel unloading machine and the reactor tank port is purged of air by the argon cleanup and cooling system, which works in conjunction with the fuel unloading machine. The two ports are opened, and a grapple descends from the fuel unloading machine into the reactor tank and engages the top of the subassembly. As the subassembly is withdrawn from the sodium pool, the grapple directs a stream of argon through it to remove the fission-product heat. After a delay to permit drainage of sodium from the surface of the subassembly, it is drawn completely into the fuel unloading machine and both ports are closed. The fuel unloading machine is then driven on its rails to the coffin loading pit.

The location, elevation, and orientation of the fuel transfer coffin at the loading pit are extremely critical. The central axis of the fuel transfer coffin must coincide with the central axis of the fuel unloading machine. The elevation of a subassembly in the coffin must correspond to the full descent of the fuel unloading machine grapple. The orientation of a key slot in the top of the subassembly must correspond to the orientation of a key in the grapple. This last requirement is imposed by the operation of the 
subassembly handling equipment, within the reactor tank, which can function properly only when the subassembly is in the correct orientation for insertion into the reactor core.

The positioning of the coffin is fixed by three holes spaced equally on the coffin support ring. The support ring rests upon a mounting ring in the loading pit, and the three holes engage three, precisely located, mounting pins. After the fuel unloading machine is driven into position above the coffin, the correct alignment of the two machines is verified by dropping two large sliding pins from the fuel unloading machine into locating sleeves on the coffin.

Flexible metal lines from the argon cleanup system are attached to valves $X$ and $Y$. Limit switches on the valve couplings indicate when the connection has been properly made and permit actuation of the gas-flow switching valves in the cleanup system. Proper rotation of valves $X$ and $Y$ permits parallel flow of argon through the coffin and the coffin circulation system. This operation purges air from the coffin atmosphere.

The fuel unloading machine is sealed to the top of the coffin, and the space between the ports is also purged of air. The two ports are thenopened, and the grapple. lowers the subassembly until it is seated within the coffin. During this operation, the subassembly is cooled by argon delivered through the grapple. When the grapple releases the subassembly and is withdrawn into the fuel unloading machine, circulation of coolant argon through the subassembly is maintained through the parallel gas-flow paths through the fuel unloading machine and the coffin. The two ports are closed, and the coolant flow continues from the gas cleanup system through the coffin. The coffin blower is turned on and operates in parallel with the external cleanup system. Valves $X$ and $Y$ are then rotated to isolate the coffin from the external system, and the gas circulation is maintained entirely by the coffin blower. This procedure ensures the uninterrupted flow of argon through the subassembly during all phases of the transfer operation.

The fuel unloading machine is then disengaged from the coffin and driven away from the loading pit. The gas circulation lines are uncoupled from valves $X$ and $Y$. The coffin is lifted out of the pit by the building crane and is placed into the equipment lock.

The lock is a large, horizontal, cylindrical tank which penetrates the wall of the reactor building containment vessel. The lock contains a cart which carries the coffin along rails from one end to the other. At each end of the lock are vertical hatches through which the coffin can pass. The coffin is driven to the far end of the lock where a 20-ton hoist lifts the coffin out of the lock and places it on a coffin transfer car. 
The transfer car is driven along rails in a passageway which joins the Reactor Building to the Fuel Cycle Facility. Just outșide the Fuel Cycle Facility is a sodium cleanup station. Here the small amount (about $40 \mathrm{~g}$ ) of sodium that covers the surface of the subassembly is removed to prevent burning of the sodium when the subassembly is finally transferred into the Air Cell of the Fuel Cycle Facility.

Flexible lines are connected from the sodium cleanup station to valves $\mathrm{X}$ and $\mathrm{Y}$ and to the bottom drain line. The sodium is converted to oxide by the addition of a small amount of moist air to the circulating argon system. The oxide is then converted to hydroxide by the further addition of moist air. The hydroxide is then washed away by passing water through the coffin cavity. During the washing cycle, the coffin blower is turned off and valves $\mathrm{X}$ and $\mathrm{Y}$ are rotated to isolate the blower and its connecting lines from the water stream. This prevents damage that may result to the blower if the lines contain water when the blower is restarted. To rotate valves $X$ and $Y$ to isolate the blower, lock pins in the valves must be removed. These pins are placed in the valves to prevent an operator from inadvertently rotating a valve to shut off the blower flow while the blower is running.

When the coffin interior has been thoroughly washed, the water stream is replaced by air flow to blow the water from the coffin and to continue cooling the subassembly. Water which is held up in the coffin is drained through the bottom outlet. The air flow is continued until the coffin interior is dry. Valves $X$ and $Y$ are rotated to permit parallel flow through the coffin from the blower and the external air supply. The blower is started, and valves $X$ and $Y$ are rotated to isolate the external air supply. The flexible lines are detached from the coffin, and the cart is driven into the high bay area of the Fuel Cycle Facility.

A 20-ton crane lifts the coffin from the cart and places it on a similar cart in the basement of the building. This cart is driven into an area underneath a shielded cell, called the Air Cell. A shielding plug in the floor of the Air Cell is set on top of the coffin to prevent exposure of operating personnel to radiation. The sliding plug in the coffin is opened, and an air-cooled grapple is lowered through the floor plug opening to grasp and raise the subassembly into the cell. The subassembly is then placed in a dismantling machine where disassembly takes place.

After the fuel material has been processed and a new subassembly has been fabricated, it is returned to the reactor by following the above procedure in reverse. Since no sodium has to be removed, the sodium cleanup procedure is by-passed. 


\section{HEAT EXCHANGER AND INSERT TUBES}

The use of the fixed, center-tube, heat exchanger and removable insert tubes contributes significantly to the simplicity and flexibility of the fuel transfer coffin. These.items will be described in greater detail below.

The heat exchanger consists of an annular tube, with longitudinal fins, which surrounds the fixed center tube of the coffin, as shown in Figure 2. The outer wall of the heat exchanger was fabricated from four flat sections of stainless steel. The fins were milled out of the flats and rolled into semicircular lengths. Two lengths were joined by longitudinal welds to form the upper half of the finned section, and the other two were similarly joined to form the lower half. The two halves were then aligned and joined by a circumferential weld. The inner wall of the heat exchanger is a smooth, thin-walled tube, joined to the finned tube at the top and bottom. Openings are provided at the bottom of the heat exchanger to permit the coolant gas to flow from the center tube into the finned annulus. The overall length of finned surface. is approximately $8 \mathrm{ft}$, and the $O D$ is $5-1 / 2$ in. The annular finned area has a minor diameter of $4 \mathrm{in}$. and a major diameter of 5-1/4 in. and contains 72 fins $1 / 4$ in. high and about $1 / 10$ in. wide. The total, finnedwall . heat transfer surface is approximately $33 \mathrm{sq} \mathrm{ft}$. The $3-5 / 8-$ in.-ID, fixed tube forms the inner wall of the heat exchanger and holds the replaceable. insert tube.

As shown in the enlarged views of Figure 2, the inner tube is welded at the top of the heat exchanger assembly. At the bottom, the tube.is free to move slightly within a retaining sleeve. This design was selected to avoid high thermal stresses which might result from large differences in temperature between the inner and outer walls of the heat exchanger. In addition, the assembly was stress-relieved to reduce further the possibility of distortion caused by heating.

An insert tube has two pins at the bottom which fit into locating holes in the bottom plate of the heat exchanger to properly orient the insert tube within the coffin. The upper edge of the insert tube forms a gas seal with the inner wall of the fixed tube. The interior of the.insert tube receives the subassembly and contains a hexagonal collar to orient the subassembly within the tube, and a seal section which prevents flow of gas coolant around the exterior of the subassembly. The manner in which a core subassembly is oriented and sealed within the insert tube is shown in Figure 2. At the bottom of the insert tube is a horizontal bar, which is straddled by the fork at the bottom of the subassembly. This bar prevents the subassembly from fully entering the insert tube if it is 60 or $120^{\circ}$ out of proper radial orientation. The bar also is used to lift the insert tube out of the coffin when it is to be replaced by a different insert tube. 
Proper positioning and orientation of the subassembly within the insert tube required that clearances be kept close. Under such conditions, slight distortion of the insert tube might result in binding between the tube and the subassembly. To reduce this risk, the insert tubes were stressrelieved by being heated for two hours at $500^{\circ} \mathrm{F}$ while suspended in a vertical position.

Three different insert tubes are used to accommodate the seven types of subassemblies that may be transferred in the coffin. The insert tube shown in Figure 2 can accept four types of subassemblies which constitute more than $90 \%$ of the transfers to be made. These are identified as core, outer blanket, inner blanket, and blanket region core subassemblies. The core subassembly contains 91 fuel pins and generates the greatest amount of fission-product heating ( $1.22 \mathrm{~kW}$ total). The other two insert tubes accommodate control and safety subassemblies. These subassemblies contain 61 fuel elements, identical to the 91 elements in the core subassembly. The smaller number of elements results in heat generation approximately $70 \%$ of that generated in the core subassembly.

To prevent hold-up of water in an insert tube above the seal and outside the subassembly, drain holes are provided just above the seal. In the insert tubes used for core and safety subassemblies, one 3/16-in.-diam drain hole is provided. This hole will permit about $10 \%$ of the coolant gas to bypass the interior of the subassembly. Since a control subassembly has much smaller orifices than the core and safety subassemblies, the pressure drop a.t a given flow ratc would be much greater. Since this condition might overload the blower system, two drain holes were provided to reduce the gas flow through the subassembly. Approximately $75 \%$ of the circulating gas will pass through a control subassembly. This flow is adequate to remove the smaller amount of heat generated.

The use of the insert tubes and the combination of orienting fixtures and seals ensure that a subassembly will be correctly located within the coffin and that the coolant gas will be directed down through the interior of the subassembly and up through the heat exchanger. The use of fins on the gas side triples the heat transfer area of this surface. The metal side is bonded to the shielding lead to eliminate gas film resistance. Thus, only a single gas-film resistance to heat transfer is encountered. The arrangement also permits the large mass of shielding lead to function as a nearly ideal heat sink.

The coffin was filled with lead in a manner which ensured a highquality bond to the heat exchanger and good contact with the external wall of the coffin. Before installation in the coffin shell, the outer wall of the heat 
exchanger was heavily tinned. Six pieces of 3 -in. structural steel angle each 12 in. long were welded to the inner surface of the coffin shell to anchor the lead. Bonding of the lead to the outer shell to enhance heat transfer is not nearly as critical as is the bonding to the heat exchanger. (Heat flux through the outside wall is much less than at the heat exchanger.) Nevertheless, the entire inside surface of the shell was sandblasted to remove the scale which is found on hot-rolled plates.

Because of the internal piping and other structural obstructions at the top of the coffin, the lead was poured with the coffin inverted. The entire assembly was preheated for $24 \mathrm{hr}$ at $500^{\circ} \mathrm{F}$. The lead was alloyed with $0.025 \%$ of calcium to minimize shrinkage, increase adhesion, and provide desired pouring characteristics. The lead was pumped from the melting vat in a continuous pour and was constantly "rodded" to aid the escape of gas bubbles and to improve bonding at the walls. When the lead had solidified, the surface was scraped flat and the bottom cover plate was welded on. After cooling, the coffin was inverted to its normal position.

The total fission heat output of a subassembly is $1.22 \mathrm{~kW}$ or $4300 \mathrm{Btu} /$ $\mathrm{hr}$. In addition to absorbing this heat; the lead must absorb the friction and compression heat transferred to the coolant gas in the circulating blower. This will be about $1000 \mathrm{Btu} / \mathrm{hr}$ under the maximum blower speed of $1450 \mathrm{rpm}$. Thus the temperature rise. in the shielding lead will be about $4.5^{\circ} / \mathrm{hr}$.* Since a normal transfer operation will require less than $4 \mathrm{hr}$, the total temperature rise in the coffin lead will be less than $18^{\circ} \mathrm{F}$. Under unusual circumstances, when a subassembly might be stored for extensive periods of time, heat loss from the large surface of the coffin to the surrounding atmosphere will prevent excessive temperatures in the lead.

The low rate of temperature rise in the lead results in essentially constant lead temperature along the heat exchanger. As a result, maximum temperature difference is maintained at the hot-gas inlet end which produces high heat-transfer rates. This condition results in essentially uniform . exhaust-gas temperature, even though variations in subassembly heat output or gas flow may occur.

The cooling capacity of the coffin was tested using a mock fuel subassembly in which the 91 fuel pins were replaced by resistance heaters to simulatefission-product heating. Thermocouples were attached to several pins to measure temperatures during the test. It had been demonstrated in other tests, and it was confirmed in this test, that the highest pin temperature

$$
\begin{aligned}
* \text { Weight of lead } & =36000 \mathrm{lb} \\
\text { Heat capacity of lead } & =0.033 \mathrm{Btu} /{ }^{\circ} \mathrm{F} / \mathrm{lb} \\
\text { Total heat input } & =5300 \mathrm{Btu} / \mathrm{hr} \\
\text { Temperature rise } & =\frac{5300}{36000 \times 0.033}=4.5^{\circ} \mathrm{F} / \mathrm{hr}
\end{aligned}
$$


occurs at the bottom of the center pin. As a design specification for the coffin, the maximum temperature of this pin was limited to $600^{\circ} \mathrm{F}$. (This is a conservative limit since pin temperatures in the reactor will be greater than $1200^{\circ} \mathrm{F}$. The relatively low, limiting pin temperature in the fuel coffin allows time to provide emergency cooling should the blower system fail.)

The tests were conducted at various heating rates and gas flow rates using air. or argon as the coolant gas. Each test at a given heating rate and flow rate was continued until essentially constant temperature was reached in the center pin. The results of these tests are shown in Figure 6 and demonstrate more than adequate cooling capacity under operating conditions. (These tests were made before the drain hole was drilled in the subassembly insert tube. The gas flow rate through the subassembly was $100 \%$ of the gas delivered by the blower. In the present design, only about $90 \%$ of the delivered gas would pass through, the subassembly. However, as shown in Figure 6, this slight reduction in gas flow rate would result in only a small. increase in maximum pin temperature.)

Figure 6

HEAT REMOVAL PERFORMANCE TESTS ON INTERBUILDING FUEL TRANSFER COFFIN

(Resistance-heated core subassembly used to simulate irradiated subassembly. Coolant: air or argon.)

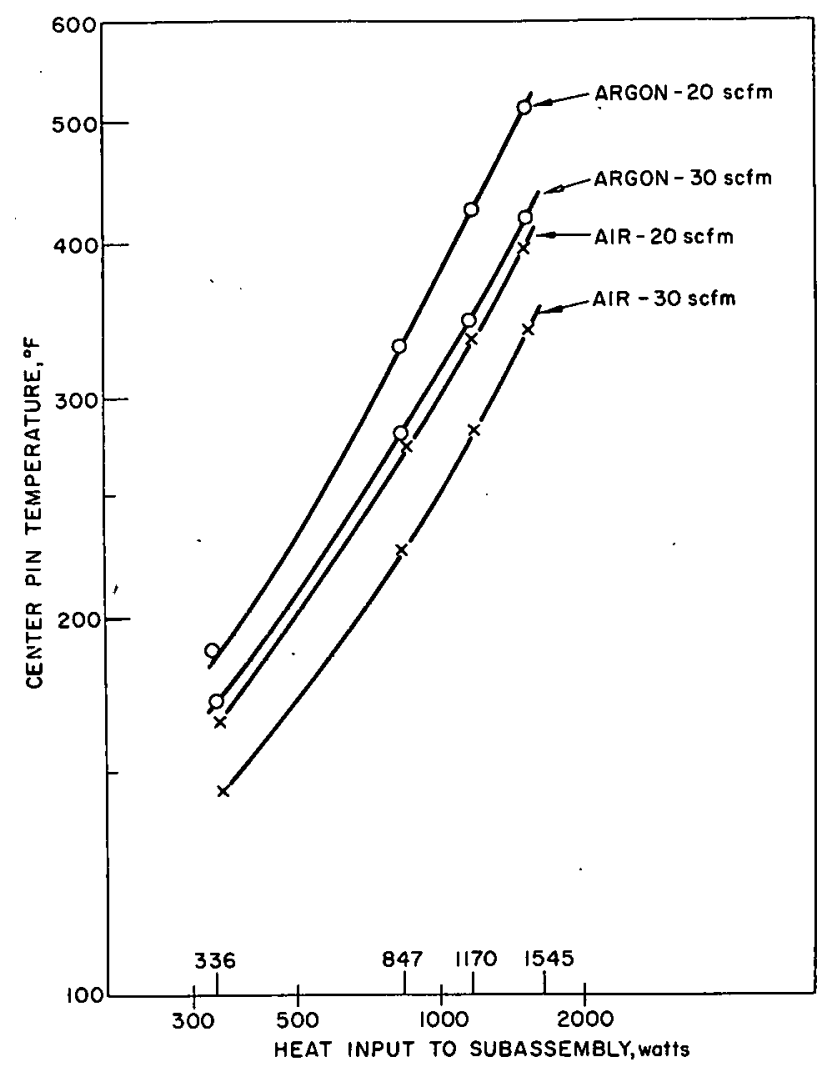




\section{SAFETY FEATURES}

The principal concern in the operation of the fuel transfer coffin is continuous removal of fission-product heat. Because it is impossible to provide for direct measurement of pin temperatures in an actual subassembly, the adequacy of cooling can be determined only by inference. The assumption is made that if the blower is operating, the coolant gas will be delivered to the subassembly. To date it has not been held necessary to have constant indication of blower speed since.speeds of 1000 to $1400 \mathrm{rpm}$ are considered adequate. Since the speed is directly related to voltage input to the motor, a voltmeter is connected to the motor circuit. The nickeliron cells are considered sufficiently reliable so that available operating: time can be predicted, and adequate warning of approaching discharge would be given by a drop in voltage. Under such circumstances, the emergency motor-generator can be connected to the motor.

A subassembly might not seat properly on the seal in the insert tube. In such a condition, if a substantial amount of coolant gas is by-passing the subassembly, this would be indicated by a decrease in the pressure drop in the circulating system.

A thermocouple is provided at the bottom of the fixed center tube at the point where coolant gas from the insert tube discharges. During the heat-transfer tests, this thermocouple gave-temperature-readings indicating a gas temperature rise approximately two-thirds of that expected on the basis of heat balance. This is because the thermocouple may not have been located at the optimum point in the gas stream, and because.no correction was made for radiant heat loss from the thermocouple to the cooler surrounding walls.

The possibility of the sudden loss of forced coolant as a result of breakage of the drive belt or failure of the motor, blower, or battery has been considered. The loss of all coolant flow would result in a rise in fuelpin temperature at a rate dependent upon the fission-product heat output in the subassembly. To determine the time available for remedial action, tests were made with the mock fuel subassembly to measure temperature rise at various heating rates. (It was established, before these tests were made, that the heat capacity of the mock assembly was essentially equal to the heat capacity of an actual fuel subassembly.) Temperature rise was measured by a thermocouple located at the center of the cluster of 91 heated pins. The temperature rise at various heating rates is shown in Figure. 7.

For any given heating rate, the time available for emergency action would depend upon the maximum pin temperature at the time of coolant failure and the maximum temperature to which the pin may be allowed to go. The temperature of the hottest pin is determined by fission heating rate and gas coolant rate. The coolant rate selected in Table I is 20 scfm air, which is about average for the various flow conditions that may exist. 


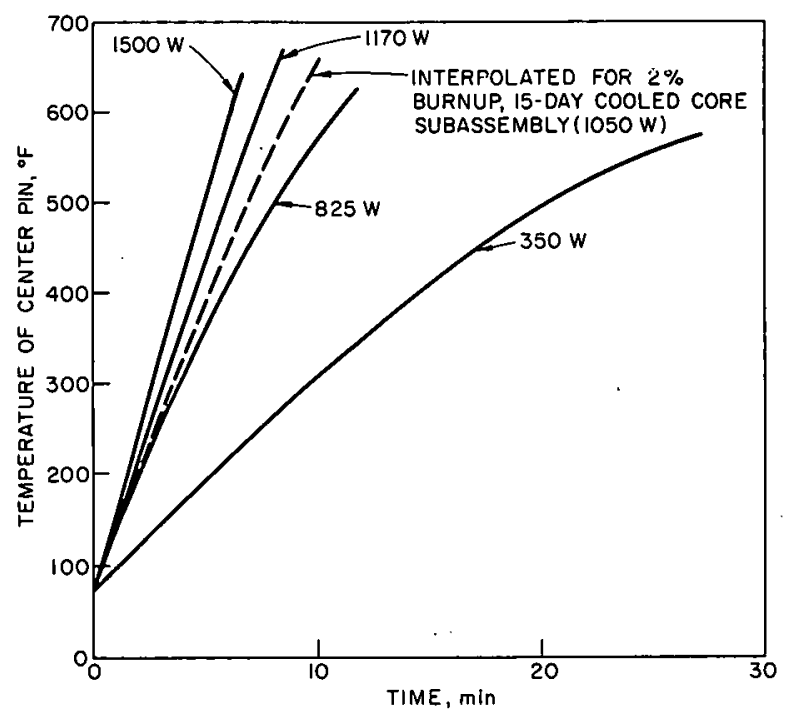

Figure 7

TEMPERATURE RISE IN

FUEL SUBASSEMBLY WITHOU T FORCED COOLING

(Test made with resistanceheated, mock fuel subas sembly)

Table I

TEMPERATURE RISE IN FUEL SUBASSEMBLY WITHIN FUEL TRANSFER COFFIN, FOLLOWING LOSS OF COOLANT

Test made with resistance-heated, mock fuel subassembly

\begin{tabular}{|c|c|c|c|c|}
\hline \multirow[b]{2}{*}{$\begin{array}{c}\text { Fission Heat } \\
(W)\end{array}$} & \multirow{2}{*}{$\begin{array}{c}\text { Hottest Pin } \\
\text { Temp. at Time } \\
\text { of Coolant } \\
\text { Fallure }\left({ }^{\prime}\right)^{a}\end{array}$} & \multicolumn{3}{|c|}{ Time (min) for Temp. to Rise to } \\
\hline & & $600^{\circ} \mathrm{F}$ & $1000^{\circ} \mathrm{F}^{\mathrm{b}}$ & $1200^{\circ} \mathrm{F}^{\mathrm{b}}$ \\
\hline 1170 & 360 & 3.2 & 9.2 & 11 \\
\hline 1050 & 340 & 4.6 & 13 & $>20$ \\
\hline 825 & 290 & 6.8 & 23 & $>30$ \\
\hline 350 & 175 & 26 & $>75$ & $\gg 75$ \\
\hline
\end{tabular}

a Pin temperature based upon coolant flow rate equivalent to 20 scfm air.

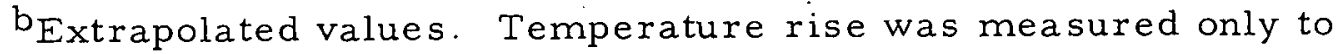
$600^{\circ} \mathrm{F}$. Curves were extrapolated beyond $600^{\circ} \mathrm{F}$ at approximately the same slope at which the curves crossed the $600^{\circ} \mathrm{F}$ ordinate. The times shown are therefore conservative.

The extreme temperature that the hottest pin may be permitted to reach is taken as $1200^{\circ} \mathrm{F}$ since this is about the temperature to which the subassembly was subjected in the reactor. If corrective action must be taken before the hottest pin reaches $1000^{\circ} \mathrm{F}$, at least 13 minutes is available when a full 2 a/o burnup subassembly is in the coffin. This will provide adequate time to replace a blower belt or to replace the battery power supply with the motor-generator power supply. 
To date no provision has been made to supply coolant ga-s to the circulating system if the motor or blower should fail. Under such circumstances, emergency cooling will be provided by filling the coffin interior with mercury. A tank filled with mercury is carried on the coffin mounted on the brackets shown between valves $X$ and $Y$ in Figure 1 . A manually operated valve in the drain line from this tank is opened to discharge the mercury into the coolant gas exit line as shown in Figure 3. The mercury will fill the interior of the subassembly, the insert tube, and the heat exchanger. Heat from the fuel pins will then flow directly through the mercury and the steel tubes into the shielding lead. Calculations have shown that. when the subassembly is coated with sodium, the heat of reaction between the sodium and mercury is easily absorbed by the mercury. For a typical case (core burnup $2 \mathrm{a} / \mathrm{o}, 15$ days cooled), where the core is assumed to reach $700^{\circ} \mathrm{F}$ due to coolant failure, the addition of the mercury would cause a rapid temperature decrease to $340^{\circ} \mathrm{F}$ with a subsequent steady-state temperature of about $125^{\circ} \mathrm{F}$ upon prolonged storage in the coffin. Replacement or repair of the motor or blower can then be made, and the new system can be tested without disturbing the contents of the coffin.

The mercury can be drained from the coffin into a sealed.receiver at the sodium cleanup station. Mercury that clings to the subassembly can be removed by flushing water through the coffin. After the subassembly has been removed from the coffin into the Air Cell, the coffin can be washed with nitric acid to remove the remaining mercury.

The operation of the coffin in conjuilclion with the fuel unloading machine has been tested satisfactorily with irradiated, sodium-coated, fuel subassemblies. Similarly, the performance of the coffin through its various transfer steps (including sodium cleanup) has also been tested. satisfactorily. The alignment of the coffin with the Air Cell floor shield has been established satisfactorily. The remote-operating grapple has been used successfully to transfer subassemblies into the Air Cell.

\section{SUMMARY}

The EBR-II Reactor at the National Reactor Testing Station in Idaho operates on a clused fuel cycle. Fuel subassemblies are removed from the reactor core after undergoing 2 a/o burnup in 135 days. Following a 15-day cooling period, a subassembly is removed from the reactor vessel and transferred to the adjoining Fuel Cycle Facility. Here the subassembly is disassembled; the fuel material is partially decontaminated in a meltrefining operation, and new subassemblies are fabricated and returned to the Reactor Building.

A fuel unloading machine removes a subassembly from the reactor vessel and then transfers the subassembly to the fuel transfer coffin. The coffin is a 20-ton, lead-shielded cask, which carries the subassembly to the 
Fuel Cycle Facility. Approximately $\mathrm{l} \mathrm{kW}$ of fission-product heat is developed within a subassembly. This heat is removed by a circulating stream of argon which passes through the subassembly, and then through an internal heat exchanger which transfers the heat to the lead shielding. The gas is circulated at 20-30 cfm by a lobe-type blower which is driven by a 1-1/4-hp motor powered by high-capacity, nickel-iron, alkaline cells which are carried on the coffin.

The coffin must pass through an equipment lock and then be carried on two separate carts to reach its unloading position in the Fuel Cycle F.a.cility. At a cleanup station along the route, a coating of sodium, which remains on the subassembly when it is extracted from the reactor, is removed within the coffin.

The coffin is equipped with quick-disconnect couplings and three-way plug valves to permit circulation of gas from its own blower or from an external source.

The heat-removal capability of the coffin has been successfully demonstrated with a mock subassembly containing heating elements in place of fuel pins.

The transfer of radioactive subassemblies between the coffin and the fuel unloading machine has been successfully demonstrated. The sodiumremoval procedure has been tested satisfactorily, and the remote-operating grapple has been used successfully to transfer subassemblies into the Air Cell.

\section{ACKNOẂ LEDGMENTS}

The authors wish to acknowledge the assistance received during the course of this work from R. C. Stimac of Central Shops, and M. S. Slawecki and M. D. Adams of the Chemical Engineering Division.

\section{REFERENCES}

1. Levenson, M., Bernstein, G., Graae, J., Coleman, L., Hampson, D., and Schraidt, J., The Pyrometallurgical Process and Plant for EBR-II, Proceedings of the Second United Nations. International Conference on the Peaceful Uses of Atomic Energy, Geneva, Switzerland (1958), 17, pp. 414-420.

2. Hesson, J:, Feldman, M., and Burris, L., Description and Proposed Operation of the Fuel Cycle Facility for the Second Experimental Breeder Reactor (EBR-II), ANL-6605, April 1963. 